\title{
Evaluation of the Impact of Climate Change on Streamflow Using SWAT Model
}

\author{
Ogbu, K.N. ${ }^{*}$, Ndulue, E.L. ${ }^{2}$, Ahaneku, I.E. ${ }^{1}$ and Ubah, J.I. ${ }^{1}$ \\ ${ }^{1}$ Department of Agric. \& Bioresources Engineering, Nnamdi Azikiwe University, Awka, Nigeria \\ ${ }^{2}$ Department of Agric. \& Bioresources Engineering, University of Nigeria, Nsukka
}

\begin{abstract}
The Soil and Water Assessment Tool (SWAT) model was applied in this study to simulate stream-flow in the Oyun River Basin. The model was calibrated and validated using monthly stream-flow data for the basin. Model performance was satisfactory for calibration and validation with a coefficient of determination $\left(\mathrm{R}^{2}\right)$ of 0.69 and 0.88 , respectively. Climate change impact on Oyun River was assessed by driving the SWAT model with climate parameters obtained from two global climate models (HadGEM2-ES and BCC-CCSM1-1M) based on RCP 2.6 for $2050-2059$ and $2080-2089$ periods. With respect to a baseline period of 2000 - 2009, HadGEM2-ES predicted a $4.62 \%$ decrease in total streamflow while the BCC-CSM1-1M predicted stream-flow increase by $6.18 \%$ for the $2050-2059$ period. However, both HadGEM2-ES and BCC-CCSM1-1M predicted stream-flow to increase by $18.92 \%$ and $\mathbf{1 1 . 2 5} \%$ respectively for the 2080 period. The HadGEM2-ES model showed consistency in relating future rainfall predictions with future discharge trends for the periods under study. Model results show the need for adaptive measures to mitigate climate change impacts on the water resource system.
\end{abstract}

Keywords: SWAT model; climate change; stream-flow; HadGEM2-ES; BCC-CCSM1-1M

\section{INTRODUCTION}

Availability of water resources is important for economic and social development of any nation. Water-related activities such as agriculture, hydropower generation, water transportation, inland fisheries and water supply provide revenue and employment, which drives economic/national growth (Kankam-Yeboah et al., 2013). Changes in climate alter runoff by affecting rainfall and temperature, which will significantly have implications on water resources (Pan et al., 2017). The hydrologic response of a watershed to changes in climate is a relevant discussion for sustainable water resources development, management and planning.

Climate change impacts on stream-flow can be evaluated either by driving hydrologic models using different climate scenarios concerning historical observations or by coupling climate model and by hydrologic model. Over the years, global climate models (GCMs) have proven to be successful in reproducing observed climate variables for use in hydrologic models (Goyal et al., 2012). Many studies have focused on using hydrologic models to establish a relationship between climate parameters and watershed hydrology (Legesse et al., 2003; Qi et al., 2009; Sead et al., 2010; Mango et al., 2011; Khoi and Suetsugi, 2014; Zuo et al., 2016; Lin and Jin, 2017; Yira et al., 2017; Yan et al., 2019). The report by the Intergovernmental Panel on Climate Change (IPCC, 2007) predicts a temperature rise of about $3-4^{\circ} \mathrm{C}$ for the West Africa region towards the end of the $21^{\text {st }}$ century. In Nigeria, studies by Okafor and Ogbu (2018), Okafor et al., (2017), Idowu et al., (2011), and Enete and Amusa (2010) have shown that climate variability is significantly affecting watershed hydrology with implications on human well-being. However, the lack of hydrometeorological data in Nigeria has greatly affected research

*Corresponding author's e-mail: kn.ogbu@unizik.edu.ng 
efforts towards this end and hence the reliance on remotely sensed data for climate impact studies on watershed hydrology. Water from the Oyun River is critical for the region's economy. It sustains the agricultural, aquaculture, recreational and hydropower generation activities in the basin (Manta et al., 2010). However, the threat of a changing climate poses farreaching consequence for this resource, thereby complicating its future development and management. This research, therefore aimed at evaluating the effects of future changes in future climate on the discharge of Oyun River using climate projections from two GCMs.

\section{MATERIALS AND METHOD}

\section{A. Theory of the SWAT Model}

This model is a physically-based, distributed and continuoustime model used for rainfall-runoff modelling at the watershed scale (Arnold et al., 1998). It comprises of many components hydrology, soil erosion, crop growth and management modules. The SWAT model can be interfaced with different geographical information system (GIS) software, which presents a userfriendly window for storing, processing and analysing heterogeneous input parameters. During model setup, the watershed is discretized into sub-basins through which flows are routed to watershed outlet. The model is computationally efficient and simulates the water balance at the hydrologic response unit (HRU) level, which is a homogeneous combination of slope, soil and land-use. The sub-basins and HRUs are determined by the user by setting the cell size within the given range. Stream-flow is routed from HRU to sub-basin to the watershed outlet and is based on the water balance model (Neitsch et al., 2011).

$$
S W_{i}=S W+\sum_{i=1}^{i}\left(R_{i}-Q_{i}-E T_{i}-P_{i}-Q R_{i}\right)
$$

where, $S W=$ soil water content; $i=$ time (day); $\mathrm{t}=$ simulation period (day); $R=\operatorname{rainfall}(\mathrm{mm}) ; Q=\operatorname{runoff}(\mathrm{mm}) ; E T=$ evapotranspiration $(\mathrm{mm}) ; P=$ percolation $(\mathrm{mm})$; and $Q R=$ return flow (MM).

\section{B. Study Area}

The Oyun River Basin is approximately $610 \mathrm{~km}^{2}$ and is in Ilorin, Kwara State, Nigeria. The inhabitants in this basin are largely farmers and cultivate corn, vegetables, cassava, rice, and rear farm animals. The region lies within the sub-humid climatic zone with a mean elevation of $251 \mathrm{~m}$ above mean sea level and a flat landscape characterized with scattered farming settlements. Major land uses within this watershed include cropland, shrubland, grassland, built-up, forest and water body. The region experiences the bi-modal peak of the rainy season (April and September), with a mean annual rainfall of $1700 \mathrm{~mm}$, mean monthly maximum $31^{\circ} \mathrm{C}$ and minimum temperature of $29^{\circ} \mathrm{C}$ (Manta et al., 2010). The Oyun River originates from an elevation of $465 \mathrm{~m}$ and flows northeast for about $80 \mathrm{~km}$ before joining the Asa River (Mustafa and Yusuf, 2012). This flows further to discharge into River Niger upstream of Jebba hydroelectric dam. The Oyun River serves as the principal source of water supply to the University of Ilorin, Nigeria and neighbouring towns.

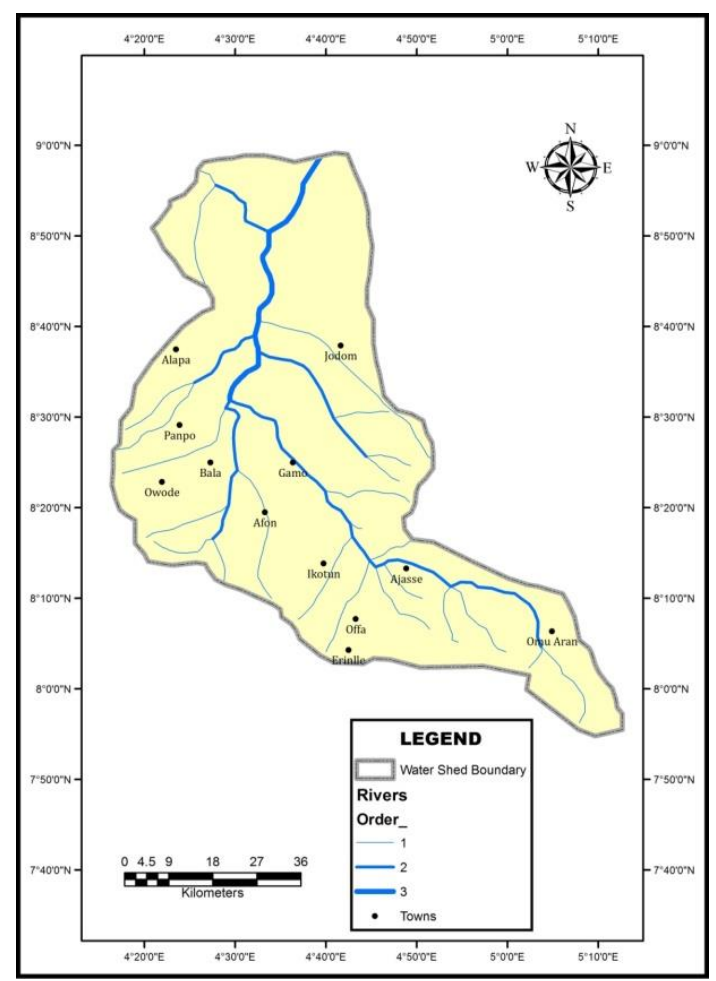

Figure 1. Oyun River Watershed, Kwara State, Nigeria 


\section{Model Input Data}

SWAT requires major input such as spatial datasets of elevation (DEM), climate and land use/cover and soil maps. A DEM of 90 $\mathrm{m}$ resolution (USGS 2006) was derived from the United State Geological Survey (USGS) Shuttle Radar Topography Mission (SRTM) website and pre-processed using the MapWindow GIS tool. Land use data of the study locations were obtained from the USGS data archive. $30 \mathrm{~m}$ resolution Landsat image data was processed and vectorized using the GIS tool. The land cover classification system of the Food and Agricultural Organization was modified to suit the land cover classes in the management component of the SWAT model for this study. Soil data were obtained from the Harmonized World Soil Database (HWSD) at a spatial resolution of $1 \mathrm{~km}$. Climate data of daily relative humidity, wind speed, rainfall, temperature, and solar radiation for the watershed were obtained from the Nigerian Meteorological Agency (NIMET).

\section{Climate Trend Analysis}

In the past, statistical methods have been widely applied in hydro-meteorological, water quality, environmental monitoring and climate studies (Oguntunde et al., 2011; Onyutha et al., 2015; Diop et al., 2017). The non-parametric test did not rely on the skewness of data or make any assumption on its underlying distribution and was used in this study. The Mann-Kendall test (Kendall, 1975) is used primarily for analysing increasing or decreasing trends over time and is stated as:

$$
\begin{aligned}
& Z=\left\{\begin{array}{c}
\frac{s-1}{[\sqrt{\operatorname{VAR}(S)}]} \text { if } S>0 \\
0 \quad \text { if } S=0 \\
\frac{s-1}{[\sqrt{\operatorname{VAR}(S)}]} \text { if } S<0
\end{array}\right. \\
& S=\sum_{k=1}^{n-1} \sum_{e=f+1}^{n} \operatorname{sign}\left(x_{e}+x_{f}\right) \\
& \operatorname{sign}\left(x_{j}-x_{k}\right)=\left\{\begin{array}{c}
x_{e}-x_{f}=1 \text { if } x_{e}-x_{f}>0 \\
x_{e}-x_{f}=0 \text { if } x_{e}-x_{f}=0 \\
x_{e}-x_{f}=-1 \text { if } x_{e}-x_{f}<0
\end{array}\right. \\
& \operatorname{VAR}(S)=\frac{1}{18}\left[\begin{array}{c}
n(n-1)(2 n-5)- \\
\sum_{p=1}^{g} t_{p}\left(t_{p}-1\right)\left(2 t_{p}+5\right)
\end{array}\right]
\end{aligned}
$$

where, $S=$ Mann-Kendall test value, $X_{e}$ and $X_{\mathrm{f}}=$ data values sequentially; $g=$ total number of tied data; $t=$ total number of data points in the gth group. The $\mathrm{H}_{\mathrm{o}}$ (null hypothesis) is rejected if $-Z_{1-\alpha / 2} \geq Z \geq Z_{1-\alpha / 2}$, where $\alpha$ is the significant level.

Positive values of $\mathrm{Z}$ signify increasing trend while negative values of Z value decreasing trend. Sen's non-parametric model is very robust and gives a more realistic slope of trend (Gocic and Trajkovic, 2013; Tabari et al., 2015). The $\left(Q_{i}\right)$ slope, for all data points, is computed as:

$$
Q i=\frac{x_{u}}{u}-\frac{x_{v}}{v} \text { for } i=1,2 \ldots . N
$$

where $Q_{i}$ is slope estimator, $x_{u}$ and $x_{v}$ are values at time $u$ and $v$ $(u>v)$.

\section{E. SWAT Model Setup}

The DEM of the watershed was delineated into seventeen subbasins and thirty-seven HRUs based on a threshold (5\%) for soil, land use and slope. Two years (2003 - 2004) of monthly stream-flow records measured at the watershed outlet, was used for calibration using the SWAT Calibration and Uncertainty Program (SWATCUP) tool (Abbaspour, 2015) and supplemented with manual method. The model validation was performed using monthly stream-flow data for $2004-2005$. Model performance for both validation and calibration periods were determined with the coefficient of determination $\left(\mathrm{R}^{2}\right)$ as stated in Equation 2. Satisfactory results are obtained when $\mathrm{R}^{2}$ $>0.5$ (Moriasi et al., 2007).

$$
R^{2}=\frac{\left[\sum\left(\hat{X}_{1}-\overline{\hat{X}}\right)\left(X_{i}-\bar{X}\right)\right]^{2}}{\sum\left(\hat{X}_{1}-\overline{\hat{X}}\right)^{2}\left(X_{i}-\bar{X}\right)^{2}}
$$

where, $\overline{\hat{X}}=$ mean of simulated; $\bar{X}=$ mean of observed values; $\hat{X}_{1}$ $=$ simulated values $; \mathrm{x}_{\mathrm{i}}=$ observed values.

\section{F. Climate Change Projections}

Climate records for two global climate models (Table 1) with Representative Concentration Pathways (RCP) of 2.6 from the $5^{\text {th }}$ phase of the Coupled Model Inter-comparison Project (CMIP5) were used in this study. 
Table 1. Climate Change Scenarios

\begin{tabular}{|l|l|l|l|l|}
\hline GCMs & Institute & $\begin{array}{l}\text { Emission } \\
\text { scenarios }\end{array}$ & $\begin{array}{l}2050 \\
\text { Timeline }\end{array}$ & $\begin{array}{l}2080 \\
\text { Timeline }\end{array}$ \\
\hline BCC- & Beijing & RCP 2.6 & $2050-$ & $2080-$ \\
& Climate $1.1 M$ & & 2059 & 2089 \\
& Centre, & & & \\
\hline HadGEM2- & China & & & \\
ES & Had. Office, & RCP 2.6 & $2050-$ & $2080-$ \\
& Centre, UK & & 2059 & 2089 \\
\hline
\end{tabular}

HadGEM2-ES = Hadley Global Environment Model 2 -

Earth System; BCC-CSM1.1M = Beijing Climate Centre

Climate System Model (V.1.1)

MarkSimGCM weather generator model which works on the principle of a third-order Markov chain process was used to produce future climate data for the 2050 and 2080 time periods while assuming an equivalent $\mathrm{CO}_{2} \sim 450 \mathrm{ppm}$ and radiative forcing of $2.6 \mathrm{~W} / \mathrm{m}^{2}$ (Van et al., 2011). The expected demographic scenarios assumed for these periods are a global population above 9 billion and high global economic growth. Projected climate variables for these periods and baseline records (2000 - 2009) were used to drive the hydrologic component of the SWAT model as described by Trotochaud et al. (2016).

\section{RESULTS AND DISCUSSION}

\section{A. Analysis of Climate Trend Variations}

Table 2 summarizes trends in relative humidity, wind speed, minimum and maximum temperature, precipitation and solar radiation in the Oyun River watershed from 1980-2013.

Table 2. Mann-Kendall Test Statistics for Annual Climate Parameters

\begin{tabular}{|l|l|l|l|l|l|}
\hline Parameter & $\begin{array}{l}\text { Initial } \\
\text { year }\end{array}$ & $\begin{array}{l}\text { Final } \\
\text { Year }\end{array}$ & $\mathbf{N}$ & $\mathbf{Z}$ & slope \\
\hline $\begin{array}{l}\text { Precipitation } \\
(\mathrm{mm})\end{array}$ & 1980 & 2013 & 34 & -2.40 & -10.40 \\
\hline $\begin{array}{l}\text { Max. } \\
\text { Temperature } \\
\left({ }^{\circ} \mathrm{C}\right)\end{array}$ & 1980 & 2013 & 34 & 2.34 & 0.034 \\
\hline $\begin{array}{l}\text { Min. } \\
\text { Temperature } \\
\left({ }^{\circ} \text { C) }\right.\end{array}$ & 1980 & 2013 & 34 & 2.13 & 0.016 \\
\hline $\begin{array}{l}\text { Relative } \\
\text { Humidity (\%) }\end{array}$ & 1980 & 2013 & 34 & -1.48 & -0.001 \\
\hline
\end{tabular}

\begin{tabular}{|l|l|l|l|l|l|}
\hline $\begin{array}{l}\text { Solar } \\
\text { Radiation } \\
\left(\mathrm{MJ} / \mathrm{m}^{2} / \text { day }\right)\end{array}$ & 1980 & 2013 & 34 & 3.91 & 0.042 \\
\hline $\begin{array}{l}\text { Wind speed } \\
(\mathrm{m} / \mathrm{s})\end{array}$ & 1980 & 2013 & 34 & -0.68 & -0.001 \\
\hline
\end{tabular}

The result shown in Table 1 signifies that that minimum temperature, maximum temperature and solar radiation solar showed a positive trend. In contrast, rainfall, wind speed and relative humidity showed a negative trend for the period considered. These results showed a similar trend to studies by Oguntunde et al. (2011) and Abiodun et al. (2011) but differed in magnitude.

\section{B. Model Calibration and Validation}

Model characteristics sensitive to runoff were obtained from Schuol and Abbaspour (2006) and used for the calibration process to get the best fit between observed and simulated stream-flow. Ranking of sensitive parameters is listed in Table 3.

Table 3. Ranking of Parameter Values (Schuol and Abbaspour, 2006)

\begin{tabular}{|c|c|c|}
\hline Parameters & Definitions & Range \\
\hline $\mathrm{CN} 2$ & Runoff CN & $62.17-71.17$ \\
\hline ESCO & Soil evaporation factor & $0.31-0.59$ \\
\hline SOL-AWC & $\begin{array}{l}\text { Saturated hydraulic } \\
\text { conductivity }\end{array}$ & $0.15-0.17$ \\
\hline GWQMN & $\begin{array}{l}\text { Threshold depth of water in } \\
\text { the shallow aquifer required } \\
\text { for return flow to occur (mm) }\end{array}$ & $\begin{array}{l}67.48 \\
127.73\end{array}$ \\
\hline SOL_Z & $\begin{array}{l}\text { Depth of soil surface from the } \\
\text { bottom layer (mm) }\end{array}$ & $\begin{array}{l}56.23 \quad- \\
67.33\end{array}$ \\
\hline ALPHA_BF & Baseflow alpha factor (days) & $0.66-1.03$ \\
\hline EPCO & Plant uptake factor & $0.16-0.41$ \\
\hline GW_DELAY & Groundwater delay & $\begin{array}{l}58.30 \\
174.99\end{array}$ \\
\hline GW_REVAP & Groundwater 'revap' factor & $0.14-0.24$ \\
\hline
\end{tabular}

A comparison of simulated and observed stream-flow at monthly time steps showed a good fit for both validation and calibration periods. Statistical analysis showed that the results are satisfactorily for calibration and validation periods with $\mathrm{R}^{2}$ 
$>$ o.6, as shown in Fig. 2 and 3, respectively. The statistical model performance is also shown in Table 4.

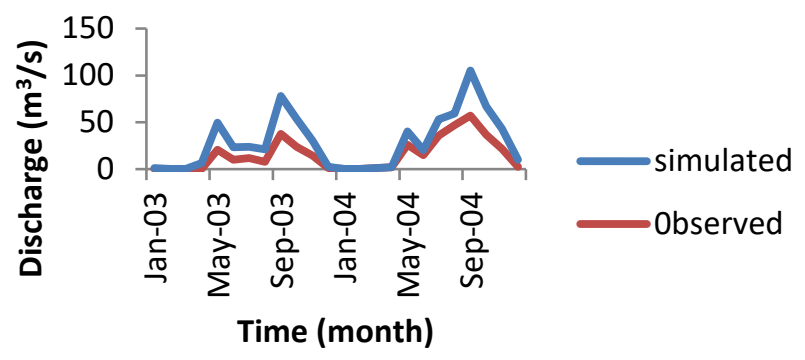

Figure 2. Calibration Plots

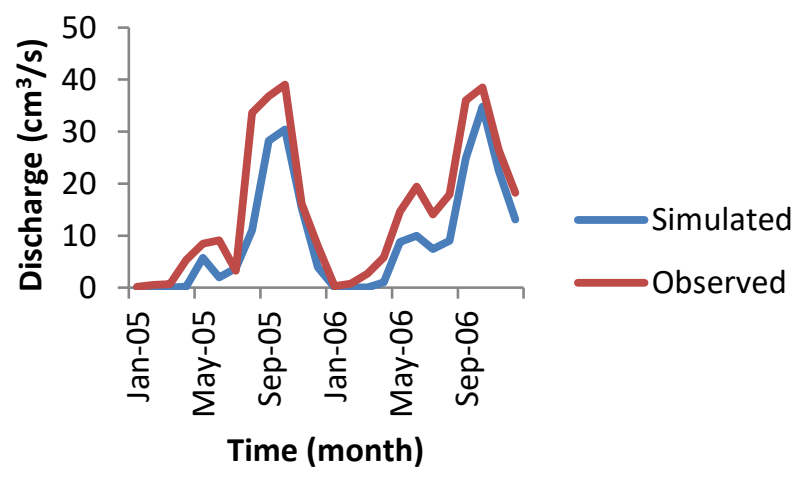

Figure 3. Validation Plot

Table 4. Model Statistical Performance

\begin{tabular}{|l|l|l|}
\hline Characteristics & Period & Coeff. of Determination $\left(\mathrm{R}^{2}\right)$ \\
\hline Calibration & $2003-2004$ & 0.69 \\
\hline Validation & $2005-2006$ & 0.88 \\
\hline
\end{tabular}

Evaluation of the average monthly observed and simulated stream-flow for calibration period and validation period show that SWAT under-predicted stream-flow by about $14 \%$ and $35 \%$ for both periods respectively. This may be attributed to the poor spatial representation of climate parameter, especially rainfall for the watershed during the period of discharge measurements. Lack of weather data necessitated the use of only one weather station, which was even located outside the study area for this study. Besides, the model result could be as a result of under-prediction of baseflow in the Oyun River basin. Kankam-Yeboah et al. (2013) observed the same trend in their study and reported that the SWAT model does not handle baseflow simulation well.

\section{Climate Projections}

A comparative study between historical and downscaled climate data show that temperature increased for all models in the future. As shown in Table 5, the average minimum and maximum temperature increase ranged from $2.89-9.10 \%$ in the future for this basin. This supports the result of Yira et al. (2017). In Table 5, it can be shown that the total mean monthly rainfall decreased by $7.17 \%$ and $\mathbf{1 1 . 1 0 \%}$ for HadGEM2ES and BCCCSM1-1M respectively for the 2050 - 2059 period but increased by 7.19\% and 9.4\% for HadGEM2ES and BCCCSM1$1 \mathrm{M}$ respectively for the $2080-2089$ period.

Table 5. Historical and Future Climate Data

\begin{tabular}{|l|l|l|l|l|l|l|l|l|l|l|l|l|l|l|l|}
\hline & \multicolumn{4}{|c|}{ Maximum Temperature } & \multicolumn{4}{|c|}{ Minimum Temperature } \\
\hline MON & HIS & $\begin{array}{l}\text { Had } \\
\mathbf{2 0 5 0}\end{array}$ & $\begin{array}{l}\text { BCC } \\
\mathbf{2 0 5 0}\end{array}$ & $\begin{array}{l}\text { Had } \\
\mathbf{2 0 8 0}\end{array}$ & $\begin{array}{l}\text { BCC } \\
\mathbf{2 0 8 0}\end{array}$ & HIS & $\begin{array}{l}\text { Had } \\
\mathbf{2 0 5 0}\end{array}$ & $\begin{array}{l}\text { BCC } \\
\mathbf{2 0 5 0}\end{array}$ & $\begin{array}{l}\text { Had } \\
\mathbf{2 0 8 0}\end{array}$ & $\begin{array}{l}\text { BCC } \\
\mathbf{2 0 8 0}\end{array}$ & $\begin{array}{l}\text { HIS } \\
\text { Had } \\
\mathbf{2 0 5 0}\end{array}$ & $\begin{array}{l}\text { BCC } \\
\mathbf{2 0 5 0}\end{array}$ & $\begin{array}{l}\text { Had } \\
\mathbf{2 0 8 0}\end{array}$ & $\begin{array}{l}\text { BCC } \\
\mathbf{2 0 8 0}\end{array}$ \\
\hline JAN & 32.6 & 34.0 & 33.9 & 34.1 & 33.5 & 18.7 & 20.5 & 20.5 & 20.2 & 20.3 & 102.3 & 93.8 & 140.0 & 75.6 & 110.7 \\
\hline MEB & 33.2 & 35.0 & 34.1 & 35.0 & 34.4 & 19.2 & 21.5 & 20.2 & 21.7 & 20.5 & 104.8 & 106.3 & 164.3 & 157.6 & 149.7 \\
\hline APR & 34.0 & 35.7 & 35.6 & 35.5 & 35.1 & 21.8 & 23.7 & 23.0 & 23.8 & 23.0 & 775.2 & 627.1 & 463.2 & 519.7 & 687.7 \\
\hline MAY & 31.9 & 35.2 & 35.0 & 35.3 & 34.5 & 22.1 & 24.1 & 23.6 & 24.1 & 23.4 & 1132.1 & 859.8 & 1033.0 & 833.6 & 1023.0 \\
\hline JUN & 29.7 & 31.5 & 30.6 & 31.5 & 30.1 & 21.6 & 23.4 & 22.6 & 23.4 & 22.4 & 1725.2 & 1778.8 & 1617.1 & 1736.9 & 1667 \\
\hline JUL & 27.2 & 28.5 & 28.6 & 28.4 & 28.5 & 19.8 & 21.6 & 20.9 & 21.5 & 20.7 & 1738.4 & 1598.6 & 1410 & 1939.3 & 1287 \\
\hline AUG & 27.4 & 28.5 & 28.5 & 28.5 & 28.3 & 20.1 & 21.8 & 21.2 & 21.7 & 21.1 & 1373.2 & 1433.9 & 1214.0 & 1690.3 & 1647 \\
\hline SEPT & 28.3 & 29.4 & 29.5 & 29.4 & 29.1 & 20.3 & 21.9 & 21.4 & 21.9 & 21.1 & 2997.9 & 2262.2 & 2675.5 & 2034.6 & 2035 \\
\hline
\end{tabular}




\begin{tabular}{|c|c|c|c|c|c|c|c|c|c|c|c|c|c|c|c|}
\hline OCT & 30.0 & 31.2 & 31.4 & 31.2 & 31.3 & 20.6 & 22.2 & 21.8 & 22.1 & 21.5 & 2076.1 & 2342.2 & 1907.5 & 2070.4 & 1777 \\
\hline $\mathrm{NOV}$ & 32.3 & 33.7 & $33 \cdot 3$ & 33.8 & 33.0 & 19.8 & 21.7 & 21.2 & 21.5 & 21.0 & 348.4 & 308.9 & 320.8 & 278.8 & 325.2 \\
\hline$\overline{\mathrm{DEC}}$ & 33.0 & 34.1 & 34.4 & 34.2 & 33.6 & 18.7 & 20.8 & 20.4 & 20.1 & 20.2 & 70.6 & 54.1 & 101.8 & 51.20 & 241.8 \\
\hline AVE & 31.1 & 32.6 & 32.3 & 32.5 & 32.0 & 20.3 & 22.2 & 21.6 & 22.1 & 21.5 & 14285.3 & 13260.9 & 12700.2 & 15313.8 & 15628 \\
\hline $\begin{array}{l}\% \\
\text { change }\end{array}$ & & +4.8 & +4.0 & +4.7 & +2.9 & & +9.1 & +6.3 & +8.6 & +5.6 & & -7.17 & -11.1 & +7.2 & +9.4 \\
\hline
\end{tabular}

Had 2050 and 2080 means HadGEM2-ES for 2050 and 2080 periods respectively; BCC 2050 and 2080 means BCC-CSM1-1M for 205O and 2080 periods respectively; (+) indicates increase while (-) indicates decrease.

\section{Climate Change Impact on Streamflow}

The influence of changes in climate on discharge is presented in Table 6. Relating the baseline period $(2000-2009)$ to the 2050 - 2059 period, HadGEM2-ES predicted that the total streamflow decreased by $4.62 \%$ while BCC-CSM1 showed that streamflow increased by $6.18 \%$. However, both models simulated stream-flow to increase in the 2080 - 2089 period. Streamflow results for the 2050 period were consistent with rainfall projection for the HadGEM2-ES model for the same period. However, the BCC-CSM1-1 model result shows a decreasing rainfall trend but projected an increase in stream-flow for the 2050 period. For the 2080 period, both GCMs showed an increasing rainfall trend with a corresponding projected increase in stream-flow.

Generally, the lack of agreement between the models concerning the projected stream-flow for the 2050 period creates uncertainty on the Oyun River discharge for the middle of the $21^{\text {st }}$ century. Yira et al. (2017) reported that such mixed stream-flow signals for future periods are prevalent in GCMenabled applications in the West African Region. This result could also be because of the high uncertainties associated with GCM outputs. Bias correction of climate parameters or averaging GCMs result could improve the accuracy of projected hydrologic dynamics of the basin. Since stream-flow is very sensitive to rainfall, this study has shown that changes in rainfall projections will have varying impacts on stream-flow, making its consideration crucial in climate change studies, especially for West African regions.
Table 6. Future Simulated Impacts of Climate Change on Streamflow

\begin{tabular}{|l|l|l|}
\hline Scenario & Streamflow & $\begin{array}{l}\text { change in } \\
\text { streamflow }\end{array}$ \\
\hline Baseline & 2633.3 & - \\
\hline $\begin{array}{l}\text { BCC-CSM1-1M (2050 } \\
\text { period) }\end{array}$ & 2796.03 & 6.18 \\
\hline $\begin{array}{l}\text { HadGEM2-ES (2050 } \\
\text { period) }\end{array}$ & 2511.72 & -4.62 \\
\hline $\begin{array}{l}\text { BCC-CSM1-1M (2080 } \\
\text { period) }\end{array}$ & 3131.64 & 18.92 \\
\hline $\begin{array}{l}\text { HadGEM2-ES (2080 } \\
\text { period) }\end{array}$ & 2929.62 & 11.25 \\
\hline
\end{tabular}

\section{CONCLUSION}

The impact of climate change on the river flow of the Oyun River watershed was assessed using the SWAT model. Model calibration and validation were simulated using monthly river discharge data for the basin. The model performed satisfactorily based on results of the coefficient of determination which was higher than 0.6 for both calibration and validation periods. Downscaled climate data from GCMs were further used to study future impacts on stream-flow. Results from HadGEM2-ES and BCC-CSM1-1 showed a decrease and increase in stream-flow respectively for the 2050 - 2059 periods while both GCMs showed an increasing runoff trend for the 2080 period. Lack of agreement between both GCMs for the 2050 period creates high uncertainty in projected stream-flow change signals and underlines the need for a larger ensemble of projections and utilizing improved climate projections for climate impact assessments in the West African region. The outcome of this research can be a decision support tool to policymakers in developing adaptive measures to 
mitigate the effect of varying climatic parameters on hydrologic systems in the sub-Saharan region.

\section{ACKNOWLEDGEMENT}

The authors acknowledge financial support from the Tertiary

Education Trust Fund (TETFUND) (TETFUND/DESS/UNIZIK/AWKA/RP/VOL.VII) of the

Federal Republic of Nigeria.

\section{REFERENCES}

Abbaspour, CK 2015, SWAT-CUP: SWAT calibration and uncertainty programs - A user manual, https://swat.tamu.edu/media/11486o/usermaunal_swatcup .pdf

Abiodun, BJ, Salami, AT \& Tadross, M 2011, Climate change scenarios for Nigeria: understanding biophysical impacts, Climate systems analysis group, Cape Town, for building Nigeria's response to climate change project, Ibadan, Nigeria: Nigerian Environmental Study/Action Team (NEST).

Arnold, JG, Srinivasan, R, Muttiah, RS \& Williams, JR 1998, 'Large area hydrologic modeling and assessment. Part 1: Model development', J. Am. Water Resour. Assoc., vol. 34, pp. $73-89$.

Diop, L, Yaseen, ZM, Bodian, A, Djaman, K \& Brown, L 2017, 'Trend analysis of stream-flow with different time scales: A case study of the upper Senegal River', ISH Journal of Hydraulic Engineering, vol. 24, no. 1, pp. 105 - 114.

Enete, AA \& Amusa, TA 2010, Challenges of agricultural adaptation to climate change in Nigeria: A synthesis, in Field Actions Science Reports.

http://factsreports.revues.org/index678.html

Gocic, M \& Trajkovic, S 2013, 'Analysis of changes in meteorological variables using Mann-Kendall and Sen's slope estimator statistical tests in Serbia. Glob.', Planet Change, vol. 100, pp. 172-182.

Goyal, MK, Burn, DH \& Ojha, CSP 2012, 'Statistical downscaling of temperatures under climate change scenarios for Thames River Basin, Canada', Int. J. Glob. Warm., vol. 4, pp. 13-30.
Idowu, AA, Ayoola, SO, Opele, AI \& Ikenweiwe, NI, 2011, 'Impact of climate change in Nigeria. Iranian Journal of Energy and Environment', vol. 2, no. 2, pp. 145 - 152.

IPCC, 2007, Impacts, adaptation and vulnerability. In contribution of Working Group II to the Fourth Assessment Report of the Intergovernmental Panel on Climate Change, eds, M. L. Parry, O. F. Canziani, J.P. Palutikof, P.J. van der Linden and C. E. Hanson. Cambridge, UK: Cambridge University Press.

Kankam-Yeboah, K, Obuobie, E, Amisigo, B \& OpukuAnkomah, Y 2013, 'Impact of climate change on stream-flow in selected river basins in Ghana', Hydrological Sciences Journal, vol. 58, no. 4, pp. 773-778.

Kendall, MG 1975, Rank correlation methods, 4th edition. Charles Griffin, London, U.K.

Khoi, DN \& Suetsugi, T 2014, 'Impact of climate and land-use changes on hydrological processes and sediment yield- a case study of the Be catchment, Vietnam', Hydrological Sciences Journal, vol. 59 (5-6), pp. 1095-1108.

Legesse, D, Vallet-Coulomb, C \& Gasse, F 2003, 'Hydrological response of a catchment to climate and land use changes in tropical Africa: case study of South-Central Ethiopia', $J$. Hydrol., vol. 275, pp. 67-85.

Lin, Z \& Jin, JM 2017, 'Evaluating climate change impacts on stream-flow variability based on a multisite multivariate GCM downscaling method in the Jing River of China', Hydrol. Earth Syst., vol. 21, pp. 5531 - 5546.

Mango, LM, Melesse, LM, McClain, V, Gann, D \& Setegn, SG2011, 'Land use and climate change impacts on the hydrology of the Upper Mara River Basin, Kenya: results of a 
modeling study to support better resource management', Hydrol. Earth Syst. Sci., vol. 15, pp. 2245-2258.

Manta, IH, Ahaneku, IE \& Pamdaya, NY 2010, 'Generation of river discharge using water balance computer model: application to River Oyun, Kwara State, Nigeria', NJTD, vol. 7, no. 2, pp. $94-103$.

Moriasi, DN, Arnold, JG, Van Liew, MW, Bingner, RL, Harmel, ZD \& Veith TL 2007, 'Model evaluation guidelines for systematic quantification of accuracy in watershed simulations', Transactions of the ASA, vol. 50, no. 3, pp. 885-900.

Mustafa, S \& Yusuf, MI 2012, A textbook of hydrology and water resources, Revised edition, Topsmerit Page Publishing co., Abuja, Nigeria.

Neitsh, SL, Arnold, JG, Kiniry, JR \& Williams, JR 2011, Soil and Water Assessment Tool, (SWAT) - theoretical documentation: version 2009, Temple, TX. US.

Oguntunde, PO, Abiodun, BJ \& Lischeid, G 2011, 'Rainfall trends in Nigeria, 1901-2000', Journal of Hydrology, vol. 411 (3-4), pp. 207-218.

Okafor, GC \& Ogbu, KN 2018, 'Assessment of the impact of climate change on the freshwater availability of Kaduna River Basin, Nigeria', Journal of Water and Land Development, vol. 38, pp. $105-114$.

Okafor, G.C, Jimoh, OD \& Larbi, KI 2017, 'Detecting changes in hydro-climatic variables during the last four decades (1975 2014) on downstream Kaduna River Catchment, Nigeria', Atmospheric and Climatic Sciences, vol. 7, no. 2, pp. 161 175 .

Onyutha, C, Tabari, H, Taye, MT, Nyandwaro, GN \& Willems, P 2015, 'Analysis of rainfall trends in the Nile River Basin', Journal of Hydro-Environment Research, vol. 13, pp. 36 51.

Pan, S, Liu, D, Wang, Z, Zhao, Q, Zou, H, Hou, Y, Liu, P \& Xiong, L 2017, 'Runoff Response to Climate and Land Use/Cover Changes under Future Scenarios', Water, vol. 9, p. 475.

Qi, S, Sun, G, Wang, Y, McNulty, SG \& Moore-Myers, JA 2009, 'Stream-flow response to climate and land-use changes in a coastal watershed in North Carolina', Transactions of the $A S A B E$, vol. 52, no 3, pp. 739-749.
Sead A, Bauwens W \& Marwa A 2010, 'Impact of Land-use change and Climate Change on the Flows in the Blue Nile River using SWAT', in unpublished Masters dissertation in Water Resources Engineering, Katholieke Universiteit Leuven.

Schuol, J \& Abbaspour, KC 2006, 'Calibration and uncertainty issues of a hydrological model (SWAT) applied to West Africa', Adv. Geosci., vol. 9, pp. 137 - 143.

Tabari, H, Taye, MT \& Willems, P 2015, 'Statistical Assessment of Precipitation Trends in the Upper Blue Nile River Basin', Stochastic Environmental Research and Risk Assessment, vol. 29, no. 7, pp. $1751-1761$.

Trotochaud, J, Flanagan, DC \& Engel, BA 2016, 'A simple technique for obtaining future climate data inputs for natural resource models', $A S A B E$, vol. 32, no. 3, pp. $371-381$.

USGS 2006, Shuttle Radar Topography Mission (SRTM) "Finished" 3-arc second SRTM format documentation, Available from:

http://edc.usgs.gov/products/elevation/srtmbil.html.

Van, V, Zetlef, P, Edmonds, J, Kainuma, M, Riahi, K, Thomson, A, Hibbard, K, Hurtt, GC, Krey, V, Lamarque, J, Masui, T, Meinshausen, M, Nakicenovic, N, Smith SJ, \& Rose, SK 2011, 'The representative concentration pathways: an overview', Climatic Change, vol. 109: p. 5.

https://doi.org/10.1007/s10584-011-0148-z.

Yan, R, Cai, Y, Li, C, Wang, X\& Liu, Q 2019, 'Hydrological responses to climate and land use changes in a watershed of the Loess Plateau, China', Sustainability, vol. 11, p. 1443. DOI: $10.3390 /$ su11051443.

Yiram Y, Diekkruger, B, Steup, G \& Bossa, AY 2017, 'Impact of climate change on hydrological conditions in a tropical West African catchment using an ensemble of climate simulations', Hydrology and Earth System Sciences, vol. 21, no. 4, pp. $2143-2161$.

Zuo, DP, Xu, ZX, Yao, WY, Jin, SY, Xiao, PQ \& Ran, DC 2016, 'Assessing the effects of changes in land use and climate on runoff and sediment yield from a watershed in the Loess Plateau of China', Sci. Total. Environ., vol. 544, pp. 238 250. 